\title{
Literatura bez granic? Media digitalne i ich wpływ na status sztuki słowa
}

\begin{abstract}
Winiecka Elżbieta, Literatura bez granic? Media digitalne i ich wpływ na status sztuki słowa [Literature without borders? Digital media and their influence on the art of words]. „Przestrzenie Teorii" 31. Poznań 2019, Adam Mickiewicz University Press, pp. 15-37. ISSN 1644-6763. DOI 10.14746/pt.2019.31.1.
\end{abstract}

The article concerns electronic literature and its place at the interface of traditional literature, technology and visual arts. This new genre of literature, associated with the development of digital media, shows that the boundaries of classical arts and disciplines in scientific research are blurring. This new phenomena require a new, transdisciplinary approach, combining literary and humanist competences with programming knowledge. The author presents a new literary phenomenon and indicates that literariness is a category which is more functional than literature in the case of studying e-literary. Literariness applies not only to literary works but also to other arts and phenomena in which it is the dominant feature of the work. This is exactly what happens in the case of electronic literature. It remains in the field of creativity in which the role of the word is the most important. At the same time, programming skills are required from the artist and the researcher, which do not fall within the scope of classical humanities. The author indicates that e-literary creativity is an area that opens up new perspectives for literary studies. It also sets new requirements for literary researchers.

KEYWORDS: electronic literature, literariness, transdisciplinarity, art and technology, digital media, Internet, theory of literature

Od 1991 roku, kiedy powstała pierwsza strona World Wide Web ${ }^{1}$, świat zmienił się nieodwracalnie. Dziś nikt nie jest wolny od skutków medialnej rewolucji, która dokonała się w ciagu minionego ćwierćwiecza. Wpływ Internetu, następnie zaś mediów społecznościowych na wszystkie aspekty ludzkiego życia (zarówno w wymiarze społecznym, jak i indywidualnym) nie budzi wątpliwości. Także status i kondycja sztuki, w tym literatury, uległy głębokim przeobrażeniom. Ta ostatnia uwolniła się od związku z medium druku i w przestrzeni komunikacji wirtualnej rozwija się wedle zmienio-

${ }^{1}$ Jej twórcą był Tim Berners-Lee, brytyjski programista, pomysłodawca i twórca ogólnoświatowego projektu systemu otwartej komunikacji, opartej na hipertekście (WWW). WWW miało umożliwić współpracę wielu autorów dzięki łączeniu informacji w sieć dokumentów (hipertekst). Najpierw, jesienią 1990 roku, został on przetestowany w Europejskim Ośrodku Badań Jądrowych (CERN, fr. l'Organisation européenne pour la recherche nucléaire - Europejska Rada Badań Jądrowych) w Genewie. W Internecie stał się dostępny latem 1991 roku. Od tej pory sieć WWW - system informacyjny działający w wolnym dostępie jako multimedialny, hipertekstowy standard usług internetowych - zdominowała Internet, rewolucjonizując przestrzeń komunikacji, w tym komunikację artystyczna, również literacka. 
nych reguł, przekraczając tradycyjne granice sztuki słowa. Pod pewnymi warunkami twierdzić można nawet, że literatura, podobnie jak inne sztuki, w dobie transmedialności i transdyscyplinarności nie ma granic. Niniejszy artykuł stanowi próbę zaprezentowania jej sytuacji w zmienionym środowisku medialnym, mierzy się z pytaniami o jej status, możliwości rozwoju i relację z innymi dziedzinami aktywności twórczej, tradycyjnie traktowanej jako odrębne dziedziny sztuki.

Najczęściej pojawiające się w związku z ekspansją technologii w kulturze pytania dotyczą statusu wytwarzanych z jej użyciem obiektów. Czy to jeszcze sztuka? - pytają odbiorcy, spoglądając na cybernetyczne projekty artystów-programistów. Działania w rzeczywistości wirtualnej, wymagające użycia skomplikowanego, bardzo wyspecjalizowanego (i kosztownego) sprzętu, budzą skojarzenia raczej z warsztatem szalonego wynalazcy niż ze sztuką. Uzmysławiają też dobitnie to, co wcześniej nie wydawało się tak istotne: że techne, czyli związanie sztuk z narzędziami służącymi do ich wytwarzania, zawsze była częścią procesu twórczego ${ }^{2}$. Użycie technik malarskich, rzeźbiarskich, pisarskich maskował jednak finalny efekt: obraz, rzeźba, wiersz, powieść. Dziś, głównie z powodu ogromnego przyspieszenia zmian technologicznych, dokonujących się na naszych oczach, wpływ wynalazków technicznych na sztukę stał się dużo bardziej widoczny, a jednocześnie znacznie trudniej uchwytny.

Posługujemy się wytworami techniki już nie tylko jako narzędziami. Nowe, niewidzialne technologie teleinformatyczne przenikają naszą rzeczywistość, wnikają w ludzką świadomość, przekształcając ją dogłębnie. Nie da się już oddzielić tego, co naturalne, od tego, co sztuczne - sztuczność wnika w samą istotę naszego świata. Doświadczamy go inaczej niż kiedyś. Głęboka więź człowieka i technologii prowadzi, zdaniem wielu badaczy, do cyborgizacji ludzkich istot ${ }^{3}$. Na naszych oczach i z naszym udziałem pisze się nowy rozdział antropologii. Jej bohaterem jest człowiek zalogowany, podłączony do urządzeń sieciowych, żyjący w poszerzonej rzeczywistości, dającej poczucie przebywania w wielu miejscach naraz. Jego mózg zmienia się pod wpływem nowych bodźców, a możliwości poznawcze i percepcyjne ulegają modyfikacji za sprawa niewidzialnych technologii oraz braku ograniczeń czasowych i przestrzennych. Jeśli dodać do tego całkiem namacalne dowody oddziaływania technologii na ludzki organizm, których dostarcza

${ }^{2} \mathrm{Na}$ temat historii pojęcia techne zob. A Doda-Wyszyńska, Pojęcie techne a filozofia przedstawienia, [w:] Filozofia technologii, red. S. Myoo, J. Hańderek, Lublin 2014, s. 7-16.

${ }^{3}$ Por. G. Gajewska, Arcy-nie-ludzkie. Przez science fiction do antropologii cyborgów, Poznań 2010; Klan cyborgów. Mariaż człowieka z technologia, red. G. Gajewska, J. Jagielski, Gniezno 2008. 
pod dostatkiem współczesna medycyna (także estetyczna), granica między ludzkim i nie-ludzkim nie tylko przestaje być oczywista, lecz coraz częściej całkiem zanika.

Jednocześnie cały czas przebiega proces wytwarzania nowych cyberobiektów, instalacji, wirtualnych performensów, których innowacyjność, zrywająca z percepcyjnymi i estetycznymi przyzwyczajeniami odbiorców sztuki, utrudnia ich akceptację. Koncepcja sztuki pojmowanej jako odrębna od innych typów działalności człowieka aktywność o szczególnych walorach estetycznych, ideowych i formalnych często okazuje się anachroniczna w obliczu eksperymentalnych dokonań twórców korzystających z najnowszych odkryć w dziedzinie nauki i wynalazków technicznych oraz biotechnologicznych, tworzacych swoje projekty w laboratoriach lub pracowniach informatycznych. Odwróciły się też relacje między możliwościami technicznymi i ich wykorzystaniem w twórczości. Coraz częściej to nie poszukiwania artystyczne prowadzą do odkrycia nowych możliwości ekspresji (czyli nowych rozwiązań formalnych), lecz nowe technologie skłaniają twórców do testowania skutków ich wykorzystania w ramach eksperymentów artystycznych. A przy tym standardowe narzędzia (na przykład cyfrowe), oferowane użytkownikom w postaci oprogramowania, ograniczają przestrzeń artystycznej wolności, dlatego stają się przedmiotem krytyki. W ich miejsce twórcy projektują własne, jednorazowe rozwiązania. Dlatego badania sztuki w perspektywie technokulturowej stanowią dziś rozległy i wielokształtny obszar, na którym spotykają się kompetencje artystów, informatyków, inżynierów, historyków sztuki, historyków idei, filozofów, filozofów nauki, kulturoznawców ${ }^{4}$. Z tego też powodu określa się niekiedy dzisiejsze czasy nowym renesansem, a artystów - mianem homo faber, wskazującym na zręcznościowy, a zarazem wymagający szczegółowej wiedzy i umiejętności charakter ich działań, mających status wytwarzania i pracy zarazem ${ }^{5}$. Świadome uczestnictwo w kulturze wymaga bowiem rozległych kompetencji,

${ }^{4}$ Stanową one odrębny problem i mają ogromną literaturę przedmiotu, do której w tym miejscu odsyłam.

${ }^{5}$ Por. P. Celiński, Postmedia: cyfrowy kod i bazy danych, Lublin 2013. Autor odwołuje się do ujęcia Hannah Arendt, która w Kondycji ludzkiej twórczego i refleksyjnego homo faber przeciwstawia animal laborans, czyli bezmyślnemu i odtwórczemu konsumentowi. Celiński, charakteryzując współczesną sytuację, posługuje się określeniami: Homo F@ber i renesans 2.0. Na marginesie dodajmy, że homo faber przeciwstawiany jest zwykle homo ludens, czyli człowiekowi zabawy. Nie można jednak zapominać, że tę sprzeczność znosi współczesna kultura. Figurą twórcy korzystającego z możliwości, jakie dają nowe technologie, staje się niejednokrotnie homo ludens. Zarówno bowiem poważny artystyczny projekt, jak i zabawa narzędziami programistycznymi stają się dziś przejawami aktywności eksperymentalnej oraz postawy krytycznej wobec nowej sytuacji kultury. 
budzacych - inna sprawa: czy słusznie? - skojarzenia z wszechstronnością mistrza renesansu Leonarda da Vinci ${ }^{6}$. Dzisiejszy artysta jest nie tylko praktykiem, lecz również komentatorem własnych działań: objaśnia tajniki wytwarzania i działania swoich dzieł, projektuje kontekst ich odbioru. Angażuje się w proces kształtowania nowej świadomości i wrażliwości odbiorców ${ }^{7}$.

Wszystkie te kwestie, coraz częściej będące przedmiotem krytycznej oraz badawczej refleksji ${ }^{8}$, nie pozostają bez wpływu na przemiany sztuki słowa, która również ulega głębokim przekształceniom za sprawą technologii cyfrowych. Pomijam w tym miejscu kwestię przemian w obrębie poetyki utworów drukowanych, te wielokrotnie były już przedmiotem analiz i opisów ${ }^{9}$. Interesuje mnie natomiast zjawisko stosunkowo nowe, związane bezpośrednio z rozwojem komputerów, a następnie Internetu i mediów społecznościowych. To bowiem eksplozja digitalności stała się powodem narodzin nowej odmiany literatury, nazywanej niekiedy w Polsce liternetem ${ }^{10}$, którą dalej określać będę mianem e-literatury, czyli literatury elektronicznej ${ }^{11}$.

Właśnie pod adresem dzieł e-literackich, które powstają i funkcjonuja w przestrzeni digitalnej, kierowane jest często pytanie o ich status i przynależność do tradycyjnych dyscyplin. Czy to jeszcze literatura? - zadaja pytania zdezorientowani studenci literaturoznawstwa, którzy na zajęciach na temat najnowszych form komunikacji literackiej poznaja eksperymentalne projekty multimedialne, w których litery, słowa i całe bloki tekstu poddane zostają niezliczonym i zaskakującym dla czytelnika tradycyjnych tekstów literackich procesom uprzestrzennienia oraz kinetyzacji, wymazy-

${ }^{6}$ Por. P. Celiński, dz. cyt., s. 64-67.

${ }^{7}$ Zjawisko to doskonale widać w przypadku utworów e-literackich, z których każdy stwarza własne, jednorazowe i niepowtarzalne reguły powstawania, działania i odbioru. Dlatego prawie każdy z dostępnych online projektów opatrzony jest odautorskim komentarzem, swoistą instrukcją obsługi, wprowadzającą nie tylko w techniczne arkana działania obiektu, lecz wskazujący na możliwe konteksty jego odbioru.

${ }^{8}$ Por. pod wieloma względami przełomowy tom rozpraw poświęcony związom sztuki, nauki i technologii w Polsce: Sztuka i technologia. Od cyberkomunizmu do kultury makerów pod red. A. Jelewskiej, Poznań 2014.

${ }^{9} \mathrm{Na}$ ten temat między innymi M. Hopfinger, Literatura i media: po $1989 \mathrm{roku}$, Warszawa 2010 i B. Bodzioch-Bryła, Ku ciału post-ludzkiemu Poezja polska po 1989 roku, Kraków 2006.

${ }^{10}$ Pierwsze polskojęzyczne opracowanie zjawisk związanych z literatura w Internecie ukazało się jako pokłosie sesji literaturoznawczej w roku 2002: Liternet. Literatura i Internet, red. P. Marecki, Kraków 2002.

${ }^{11}$ Pierwszym utworem, który uznany został za reprezentanta nowego gatunku e-lit (anglojęzyczny skrót pełnej nazwy), był powstały w 1952 roku komputerowy algorytm wytwarzający miłosne listy, autorstwa brytyjskiego informatyka Christophera Stracheya. Love Letter Algorithm generował wiersze, które miały charakter queerowej krytyki heteronormatywnych wzorców miłosnych wyznań. 
wania, znikania oraz pojawiania się, multiplikacji, animacji, rearanżacji, intensyfikacji itd. za sprawą współobecności innych niż językowe środków ekspresji oraz możliwości technicznych, jakie daje oprogramowanie. Zazwyczaj podczas studiów stykają się oni po raz pierwszy z realizowanymi i osadzonymi w cyfrowym środowisku utworami (choć określenie to nie do końca adekwatnie odzwierciedla ich płynny, otwarty charakter, do czego jeszcze wrócę), które często w niewielkim tylko stopniu przypominają klasyczną sztukę słowa.

Tak postawione pytanie zakłada jednak, że istnieje jakiś zespół cech ponadczasowych i stanowiących niezbędne ontologiczne minimum - które spełnić musi dzieło sztuki słowa, tymczasem okazuje się, że problem ten jest dużo bardziej złożony. Zanim zatem wyjaśnimy, czym właściwie jest e-literatura, zrekonstruować trzeba kontekst, w którym te hybrydyczne, niepokojące byty niedające się wpisać w żadną ze znanych dotąd formuł literackości zaczęły powstawać.

Współczesny stan kultury określany jest nie bez powodu trans-, a nawet postdycyplinarnym. Zacierają się granice pomiędzy tradycyjnymi dziedzinami twórczości, co najlepiej widać na przykładzie tych najbardziej konserwatywnych dotąd, związanych z jednym medium, do których zalicza się literatura. I nie chodzi już tylko o metodologiczną świadomość nieautonomiczności i niedefiniowalności literatury oraz o pożytki płynące z badań kulturowych nad tekstami literackimi. W środowisku digitalnym literatura, określana dotąd synonimicznie mianem sztuki słowa, wchodzi w szczególną relację z innymi kodami semiotycznymi i innymi dziedzinami twórczości. Najwyraźniejszy jest jej związek z filmem, sztukami wizualnymi oraz grami wideo, choć pole potencjalnych nawiązań jest nieograniczone. Łączy się $\mathrm{z}$ nimi już nie $\mathrm{w}$ porządku intersemiotycznym, lecz nowym, trudnym do określenia w języku literaturoznawstwa wymiarze. Literatura elektroniczna stała się bowiem częścią zjawisk związanych z procesem ucyfrowienia oraz wynikającej z niego konwergencji mediów.

Przejście od kultury mediów analogowych do kultury cyfrowej jest dla interesującego nas problemu zjawiskiem kluczowym. Obserwujemy dematerializację przekazów, które dotąd nierozłącznie wiązały się ze swoim materialnym nośnikiem. Jak dla malarstwa medium stanowiło zagruntowane płótno pokryte farba, dla fotografii światłoczuła klisza i odpowiedni papier, dla muzyki fonograf, winylowe płyty, czy wreszcie magnetyczna taśma, tak dla literatury - najpierw rękopiśmienne, a potem drukowane woluminy. Tymczasem wraz z wynalezieniem nowej technologii komunikacji cyfrowej wszystkie formy przekazu, wytworzone w kodzie digitalnym lub na format cyfrowy przetransformowane (czyli ucyfrowione), utraciły swą odrębność, właściwości fizyczne oraz reguły wytwarzania. Wszystkie bez różnicy maja 
(na poziomie ukrytego dla odbiorcy kodu źródłowego) status zapisu zerojedynkowego. Jak klarownie tłumaczy Piotr Celiński, „W domenie cyfrowej wymazane zostały różnice pomiędzy poszczególnymi mediami epoki analogowej. Wchodząc do cyfrowego świata, zostały one pozbawione wielu swoich szczególnych, materialnych i gramatycznych cech, reguł i kształtów [...]”12.

Nietrudno zauważyć, że kluczowym pojęciem jest tutaj kategoria medium, które rozumieć należy nie tylko jako techniczne zapośredniczenie komunikacji między nadawcą i odbiorca. Media to, zgodnie z ujęciem amerykańskiej historyczki mediów Lisy Gitelman,

społecznie realizowane struktury komunikacji, które zawieraja zarówno formy technologiczne, jak i związane z nimi protokoły i gdzie komunikacja jest praktyka kulturowa, zrytualizowanymi więziami ludzi poruszających się na tej samej mapie mentalnej, zaangażowanych w popularne ontologie reprezentacji i współdzielących je. [...] Jeśli media zawierają to, co nazywam protokołami, obejmują one ogromna ilość normatywnych reguł i warunków domyślnych, które gromadzą się i przylegają jak mglisty układ wokół technologicznego jądra. Protokoły wyrażają ogromną różnorodność relacji społecznych, ekonomicznych i materialnych ${ }^{13}$.

W tak szeroko, z uwzględnieniem historycznego, kulturowego i społecznego kontekstu, skonstruowanej definicji mieszczą się również sztuki, które stanowią połączenie cech swoich technicznych nośników z dyktowanymi przez nie kulturowymi protokołami, kształtującymi określone zachowania i formy uczestnictwa w kulturze. I tak literatura jako sztuka będąca medium w rozumieniu Gitelman, rozpowszechniona w postaci drukowanej książki, odgrywa określoną rolę społeczną i kulturotwórczą. Dostępna jest dla tych grup społecznych, które stać na zakup książki, wyznacza (przynajmniej do pewnego stopnia) status społeczny osoby, świadczy również o jej kapitale kulturowym. Samo czytanie książki wymaga stosowania określonych zasad: czytamy od pierwszej do ostatniej strony, od górnego do dolnego wersu, od lewej strony do prawej, w pozycji dla nas najwygodniejszej, na którą pozwalają poręczny kształt i waga woluminu. Także i to, że fragmenty powieści podzielonej na rozdziały potrafimy uspójnić jako odnoszące się do jednego świata; to, że żywiąc uczucia do literackich bohaterów, nie wierzymy w ich istnienie i że w fabule powieściowej nie szukamy prostego odbicia faktów, wynika z kompetencji kulturowych podlegających systemowym regulacjom. Podobne uregulowane kulturowe praktyki wymuszaja, rzecz jasna, inne typy komunikacji (telefonowanie, pisanie e-maili itp.), w tym inne dziedziny sztuki. Aby na przykład obejrzeć spektakl, należy wcześniej kupić bilet i pójść

${ }^{12}$ P. Celiński, dz. cyt., s. 16.

${ }^{13}$ L. Gitelman, Always Already New. Media, History, and the Data of Culture, Cambridge 2006, s. 7 [przekład - E.W.]. 
do teatru. W teatrze należy zachowywać się zgodnie z ustalonymi regułami. Konwencje teatralnego przedstawienia pozwalają widzowi połączyć poszczególne sceny i akty w jedną opowieść, nawet jeśli łączność między nimi nie jest oczywista. Sceniczna scenografia traktowana jest jako element świata przedstawionego, a nie fragment rzeczywistości. Te i wiele innych reguł składają się na złożona, podlegającą historycznym przekształceniom całość.

Powyższe wyjaśnienie, odnoszące się do rzeczywistości klasycznych sztuk w kulturze sprzed cyfrowej rewolucji, pozwala unaocznić istotę zmiany, która dokonuje się w cyberkulturze. Otóż w dobie konwergencji mediów, czyli zjawiska ich upodobnienia się do siebie, tracą one techniczne cechy różnicujące. Za sprawą digitalizacji kultury zniwelowane zostały granice pomiędzy poszczególnymi sztukami. Badacz mediów Lev Manovich obwieścił wprost, że koncepcja medium straciła w cyberkulturze znaczenie ${ }^{14}$. Internet stał się miejscem, gdzie - w postaci zdematerializowanej, cyfrowej - dostępne są wszystkie te przekazy, sztuki i media, które dotąd funkcjonowały w odmiennych środkach według odmiennych reguł. Medioznawcy określają ten stan jako przejście od fazy mediów do fazy interfejsów, co oznacza tyle, że różnice między poszczególnymi przekazami widoczne sa jedynie na powierzchni, na poziomie komunikatu widzialnego dla odbiorcy, natomiast reguły ich wytwarzania zostają ujednolicone. Raz jeszcze przywołajmy komentarz Piotra Celińskiego:

W domenie cyfrowej historyczne gramatyki mediów obowiązują jednakowe zasady. Wszystkie cyfrowe dane obowiąuje tu równość wobec kodu, fizycznych zasad elektryczności i hardware oraz tłumaczących je kulturze interfejsów. Poddają się one programowaniu, adaptuja swoje zasoby do wymogów strukturalnych baz danych i sieciowych protokołów komunikacyjnych, wzajemnej synchronizacji i wymieszania itd. - stają się po prostu bazami danych, ciagami cyfrowego kodu zer i jedynek, którymi można za pomoca dowolnych algorytmów zarządzać zgodnie z regułami cybernetycznej wiedzy i możliwościami obowiązujących interfejsów użytkowych ${ }^{15}$.

To wyjaśnienie, brzmiące może nieco obco w uchu humanisty, wydaje się niezbędne do tego, by móc wyjaśnić ontologię e-literatury (a także wszystkich innych sztuk w technokulturze). Funkcjonując w środowisku cyfrowym, utraciła ona swoją właściwość odrębnego, możliwego do oddzielenia i izolacji od innych form medialnych, komunikatu językowego. Internet stanowi multimedialny ekosystem, w którym trudno wyznaczyć granice pomiędzy poszczególnymi formami, semiotycznymi kodami i systemami znaczeń. Nie dlatego, że ich nie ma, lecz dlatego, że wszystkie one podlegają takim samym

${ }^{14}$ Por. L. Manovich, Estetyka postmedialna, przeł. E. Wojtowicz, [w:] Redefinicja pojęcia sztuka: ponowoczesność i wielokulturowość, pod red. J. Dąbkowskiej-Zydroń, Poznań 2006, s. $105-116$.

${ }^{15}$ P. Celiński, dz. cyt., s. 17. 
regułom łączenia i wymienności, co powoduje, że cyfrowość „,skutecznie wymazuje kulturowy sens medium, techniczne kształty i dotychczas istniejąca strukturę komunikacyjnego ekosystemu kultury"16.

Przyglądając się pojedynczym mediom w przestrzeni Internetu, należy zatem mieć na uwadze to, że interfejs (czyli przestrzeń kontaktu z urządzeniem, która umożliwia nam obcowanie z przekazem, czyniąc go widzialnym i rozpoznawalnym) nie stanowi ostatecznego i niezmiennego obiektu, który podlegać mógłby interpretacji w izolacji od jego technologicznego zaplecza i kontekstu oraz od relacji z innymi przekazami. Komputer, dziś dodatkowo podłączony do sieci, stanowi metamedium, czyli jest, zgodnie z definicja Alana Kaya, formą medium zawierająca w sobie wszystkie inne media ${ }^{17}$. Natomiast polski teoretyk mediów Piotr Celiński używa terminu postmedia, który wskazuje przede wszystkim na zatarcie w cyberświecie granic pomiędzy przekazami, konstytutywnych dla ich historycznych, analogowych poprzedników.

Z tego powodu w odniesieniu do wytworów e-literatury stosuje się niekiedy formułę „literatura bez granic”, paraliteratura, postliteratura lub literatura transmedialna. Wszystkie te określenia sygnalizują odmienność sytuacji twórczości słownej w Internecie, ponieważ jednak każde ze sformułowań narzuca już pewien wartościujący sposób myślenia o relacji między literatura drukowaną i cyfrowa jako jej fazie w pewnym stopniu zepsutej, schyłkowej, niepełnej, poprzestanę tu na neutralnym określeniu rozpowszechnionym w badaniach zachodnich, ponieważ, wskazując na zmienioną ontologię, otwiera dla niej szerokie perspektywy badań, nie narzucając z góry wartościowania.

Przede wszystkim utwory te wytwarzane są i dostępne jedynie w medium elektronicznym (digital born) - nie da się ich wydrukować i czytać tak, jak literaturę drukowana, podczas prób przeniesienia na papier tracą bowiem swoje właściwości. Już ten fakt ontologicznej zależności od cyfrowej technologii powoduje głębokie przekształcenia zarówno w naturze e-literackiego projektu, jak i w nastawieniu odbiorców. Każda zmiana nośnika - z drukowanej kartki na audiobook lub e-book - powoduje bowiem zmianę percepcyjnych wrażeń i możliwości odbiorcy. A pamiętajmy, że utwory e-literackie nie są ucyfrowioną wersją dzieł drukowanych. To obiekty, dla których istnienia technologia cyfrowa stanowi warunek sine qua non. To właśnie w sytuacji obcowania z literaturą elektroniczną uzmysłowić sobie musimy, jak istotne

${ }^{16}$ Tamże, s. 18.

${ }^{17}$ A. Kay, Personal dynamic media, [w:] The New Media Reader, eds N. Wardrip Fruin, N. Montfort, Cambridge 2003, s. 393-404. Por. podobne ujęcie: L. Manovich, Język nowych mediów, przeł. P. Cypryański, Warszawa 2006; tenże, Awangarda jako software, „Kwartalnik Filmowy" 2001, nr 35-36, s. 332. 
dla procesu rozumienia i konstytuowania się znaczeń jest nie tylko to, co czytamy, lecz również to, z czego czytamy ${ }^{18}$. Medium techniczne dyktuje nam warunki, możliwości, limituje przestrzeń naszej odbiorczej wolności, ale też wpływa na charakter utworu. Wszystkie zatem kolejne cechy e-literatury sa pochodna jej digitalnego statusu. Hipertekstowa struktura wielu utworów zmusza do lektury niesekwencyjnej, która często przypomina błądzenie po labiryncie w poszukiwaniu właściwej ścieżki. Zasadniczą nowością jest uczasowienie i uprzestrzennienie literatury. Słowa na ekranie odzyskuja brzmienie zapomniane w kulturze druku, istotną rolę może odgrywać też ich wygląd: wielkość, rodzaj czcionki, relacje z innymi graficznymi elementami przekazu. Wizualizowane są nie tylko słowa, których typografia staje się znacząca, ale też niekiedy struktura utworu, kiedy właściwemu hipertekstowi towarzyszy mapa obrazująca system połączeń między leksjami, pozwalający czytelnikowi zorientować się w przebiegach fabularnych. Dzieło jest dynamicznym, procesualnym dzianiem się, a nie statycznym obiektem - tekstem do czytania. To przekształcenie z gotowego dzieła w proces niekiedy bardziej przypomina swoją potencjalnością partyturę muzyczna. Z tego powodu użycie w stosunku do e-literatury określenia 'utwór', które sugeruje skończoność i stabilność jego kształtu, jest dość mylące. W wielu przypadkach nie istnieje jedna wersja utworu, lecz wiele jego wariantów. Tak dzieje się w przypadku hipertekstów, których przejście pozostawia każdego odbiorcę z odmiennym wyobrażeniem na temat kształtu i przebiegu fabuły. Z procesualnościa wyłaniania się utworu w swoim interfejsowym (widzialnym) kształcie wiąże się interaktywność wielu z nich - wymagają one fizycznego zaangażowania odbiorcy w akt przechodzenia do kolejnych faz utworu. Wiazać się to może z koniecznościa podjęcia konkretnych decyzji co do wyboru przebiegu utworu (kliknięcie w wybrany link, odpowiedź na pytanie, wybór spomiędzy dwóch możliwości). Za każdym razem decyzja czytelnika nie jest jednak podejmowana z pełną świadomością jej skutków, to znaczy czytelnik nie wie, jakie konsekwencje będzie miał jego wybór dla dalszego przebiegu utworu. Ta cecha zbliża e-literaturę do gier wideo: elementy rozgrywki spotykają się $\mathrm{w}$ wielu utworach z nowymi technikami prowadzenia narracji. Lekturze towarzyszyć mogą liczne efekty kinetyczne i animacyjne, wzmacniające semantykę tekstu werbalnego, ale też po prostu modyfikujące jego odbiór. $\mathrm{W}$ wielu utworach czytelnik pozostaje jednak bierny i skazany jest na oglądanie kolejnych faz tekstu bez wpływu na tempo ich pojawiania się i znikania. Ten typ odbioru również, co oczywiste, wpływa na percepcję, uniemożliwia bowiem regulowanie tempa lektury (to na przykład przypadek wideopezji,

${ }^{18}$ E.J. Aarseth, Cybertekst. Spojrzenia na literaturę ergodyczna, przedmowa M. Tabaczyński, przeł. D. Sikora, M. Pisarski, P. Schreiber, M. Tabaczyński, Kraków 2014. 
ale też generatywnego poematu booms Piotra Puldziana Płucienniczaka). Często nieczytelność z tym związana staje się zamierzonym i pożądanym efektem. W dziedzinie grafiki, typografii i szeroko pojmowanej sfery wizualnej e-literatura nie ma praktycznie żadnych ograniczeń poza tymi, które stawia technologia. To, co widzimy na ekranie, jakiego rodzaju obrazy, grafiki i efekty wizualne towarzyszą lekturze, ma, co oczywiste, przemożny wpływ na sposób odbioru utworu i jego interpretacje. Podobnie dzieje się ze sfera audialna, która nie tylko buduje nastrój, ale też dysharmonijnie zakłóca odbiór, budzi niepokój - i zawsze wzbogaca semantykę przekazu werbalnego oraz modyfikuje jego percepcję. Na koniec tego krótkiego katalogu nowości wprowadzanych do poetyki e-literatury warto wspomnieć o utworach, które robią wrażenie pisanych przez maszynę - różnego rodzaju generatory, w których kolejne elementy zaczerpywane się z zamkniętych lub otwartych baz danych, a następnie łączone zgodnie $\mathrm{z}$ algorytmem. Nawet jednak w takich przypadkach należy pamiętać o tym, że za wszystkimi, nawet najbardziej zmechanizowanymi i odpodmiotowionymi zjawiskami stoi twórca - artysta-programista, który projektuje (przynajmniej do pewnego stopnia) reguły działania i przebiegu e-literackiego utworu.

Przyglądając się różnorodnym i nieustannie poszerzajacym się nowym propozycjom, łączącym specyficzne walory komunikacji literackiej z możliwościami technologii, otwierającej słowo na kooperację z innymi kodami i sztukami, uznać można, że pole literatury w XXI wieku, wbrew diagnozom pesymistów, wcale się nie kurczy. Zmienia się jednak nieustannie, poddając próbie trwałość i aktualność tradycyjnych definicji. Obszar literackich eksperymentów rozrasta się, nie tylko wchłaniając formy i style wcześniej traktowane jako z gruntu nieliterackie: użytkowe, potoczne, trywialne. Wiek XX, który upłynął pod znakiem rozwoju audiowizualności, wzbogacił twórczość literacką o nowe techniki opowiadania, montażu i obrazowania, inspirowane przez wynalazki takie jak film, radio, wreszcie telewizja. Dopóki literatura związana była z formą drukowanego kodeksu, granice eksperymentów w obrębie literackiej ekspresji wytyczały techniczne możliwości druku. Spory o to, czym jest literatura oraz w czym przejawia się literackość tekstu, nie podawały w wątpliwość jej cechy fundamentalnej: tego, że jest ekspresją językowa. Pogranicza i korespondencje sztuk, badane przez literaturoznawców, pokazywały jedynie złożoność relacji, w jakie wchodzi literatura. Nawiązania, pokrewieństwa i aluzje miały charakter metafor, strukturalnych paralel, realizowanych środkami właściwymi komunikacji werbalnej. Nie przekraczały granic ekspresji językowej. Literatura pozostała sztuką słowa, bo to język jest jej materia, jak dla muzyki dźwięk, zaś dla malarstwa plama barwna. 
Tymczasem dziś zmiana myślenia o losie literatury i literackości wymuszona jest przez dużo bardziej zasadnicze niż metodologiczne kwestie. Humanistyka znalazła się w sytuacji, w której technika i kultura, wcześniej funkcjonujące niezależnie, stanowią jeden, nierozdzielny twór, nazywany technokulturą ${ }^{19}$.

Badacz literaturoznawca pyta o właściwości języka oraz specyfikę komunikacji literackiej w obrębie Internetu. Okazuje się jednak, że nie jest w stanie odpowiedzieć na wszystkie swoje pytania, nie zadając także tych przekraczających dotychczasowe granice jego kompetencji. Pytanie o właściwości komunikacji wirtualnej prowadzi do wiedzy z zakresu teorii informacji i cybernetyki (w której skądinąd dwudziestowieczne literaturoznawstwo strukturalistyczne jest zadłużone). Próba znalezienia odpowiedzi na pytanie o relację słowa i innych kodów wykorzystywanych w utworach online wymaga od badacza wiedzy nie tylko z zakresu historii sztuki oraz semiotyki, lecz także z zakresu technologii cyfrowej, czyli informatyki (a nawet dalej - fizyki kwantowej, dzięki której Internet działa). Nie tylko dlatego, że w jednym dziele spotyka się kod wizualny, dźwiękowy i werbalny dzięki technologii, która umożliwia swobodne łączenie, przetwarzanie obiektów digitalnych. Także - a może: przede wszystkim - dlatego że wiele elementów poetyki (czyli wytwarzania i budowy) nowych obiektów zostało przez nią umożliwionych - bez niej by nie zaistniały. Dotyczy to na przykład zjawiska spacjalności i czasowości dzieła. W badaniach nad literaturą drukowaną do właściwego odczytania utworu literackiego niezbędne jest przede wszystkim zapoznanie się z nim w całości, związane z możliwością dostępu do całej jego struktury, co dopiero pozwala na pełną analizę relacji między poszczególnymi elementami. Tymczasem wiele utworów e-literackich wykorzystuje możliwości dynamizacji obiektów - zarówno w technologii 3D, jak i dzięki prostym i bardziej zaawansowanym animacjom (rendering, rozmycie ruchu, tweening, animacja proceduralna, symulacja zjawisk fizycznych, zaawansowane techniki motion capture, czyli rejestrowanie ruchu użytkownika za pomoca sensorów i odtwarzanie ich na ekranie). Z tego powodu nie tylko niemożliwe jest ogarnięcie „całości” tekstu e-literackiego, którego kolejne fazy zależne są od wcześniejszych wyborów czytelnika, ale też każdy czytający ma do czynienia z innym wariantem utworu.

Stopień wykorzystania zaawansowanych technologii w budowanie dzieła e-literackiego jest bardzo zróżnicowany, każde z nich w zupełnie inny

${ }^{19}$ Analogicznym pojęciem posługują się badacze pogranicznych kwestii i relacji między kulturą i natura, którzy z kolei mówią o naturo-kulturze lub trzeciej kulturze, co wskazuje na ontologiczną nierozdzielność kategorii, które spotkały się nie tylko w obrębie metodologicznej refleksji podejmowanej w prowadzonych dzisiaj badaniach, lecz nade wszystko i w pierwszej kolejności - w doświadczeniu uczestników. 
sposób wykorzystuje literacki potencjał języka. Dlatego użyteczna wydaje się kategoria literackości, która pozwala jasno wskazać na stopniowalność natężenia zjawiska wykorzystania wielorakich właściwości słowa i opisywać jego obecność także w tych projektach, które do literatury już nie należa.

Literackość oznacza - zespół cech identyfikowanych jako właściwe sztuce słowa, które jednak odnaleźć można w różnym natężeniu i konfiguracji także w innych sztukach. Na pytanie, czym jest literackość, z mistrzowską precyzja strukturalisty odpowiedział Edward Balcerzan ${ }^{20}$. Promując swoją koncepcję literackości jako modelu, wskazał zarazem wiele cech w obszarze praktyk piśmienniczych, z którymi nie sposób się nie zgodzić i które pozwalaja zrekonstruować wyobrażenie, czym jest omawiana wartość. Po pierwsze zatem, „literackość stanowi jakość komunikacyjna, uobecnia się sytuacyjnie" ${ }^{21}$. Sposób jej postrzegania oraz funkcjonowania zależy od kulturowego obszaru, w którym się ujawnia. Z tego wynika druga cecha, ta mianowicie, że „literackość może się uobecniać poza literatura, nie tracąc swych wyznaczników podstawowych" ${ }^{22}$. Nie jest przy tym przypisana żadnej substancjalnej właściwości dzieła, a szukać jej trzeba „w relacjach między składnikami tekstu"23.

Jak widać, Balcerzan rezygnuje z podejmowanych wielokrotnie przez teoretyków literatury prób poszukiwania w utworach konkretnych cech o kwantyfikatorze literackim (obrazowość, fikcyjność, nadorganizacja języka i figuratywność, spójność elementów, wieloznaczność, autoteliczność, intertekstualność itd.), proponując w zamian sprzecznościową koncepcję literackości, koncepcję bardziej uniwersalna, polegającą

na uwyraźnieniu i jednoczesnym zawieszeniu obowiązującej poza sztuką słowa formalno-logicznej normy niesprzeczności (lex contraditionis), wedle której nie mogą być uznane za równocześnie prawdziwe dwa przeciwstawne sądy na temat tego samego przedmiotu, ujęte w tym samym trwaniu i w identycznym ukierunkowaniu. W komunikacji praktycznej nie jest dopuszczalne, by coś jednocześnie było A i nie-A; w komunikacji literackiej - odwrotnie - jest to nie tylko nagminne, ale i nieodzowne ${ }^{24}$.

Aby ta sprzecznościowa reguła działała, Balcerzan przyjmuje Łotmanowskie rozumienie granic, zgodnie z którym „ten sam tekst literacki, wypowiedziany w bezpośredniej rozmowie i zamknięty w ramie literackiego utworu, nie jest tym samym tekstem" ${ }^{25}$.

${ }^{20}$ E. Balcerzan, Literackość. Modele, gradacje, eksperymenty, Toruń 2013.

${ }^{21}$ Tamże, s. 44. W oryginale tekst zapisany wersalikami.

${ }^{22}$ Tamże, s. 45. W oryginale tekst zapisany wersalikami.

${ }^{23}$ Tamże, s. 54. W oryginale tekst zapisany wersalikami.

${ }_{24}$ Tamże, s. 57.

${ }^{25}$ Tamże, s. 131. W oryginale tekst zapisany wersalikami. 
Kłopot z tak sformułowaną definicją polega jednak na tym, że wymaga ona uznania niezmienności modelu literackości, którego wszelkie przejawy sa tylko wariantami jednego inwariantu, co czyni go uniwersalnym wyróżnikiem wszystkich potencjalnie możliwych do pomyślenia i realizacji dzieł sztuki literackiej. Tymczasem w przypadku projektów e-literackich te reguły odbioru literatury bywaja głęboko modyfikowane przez technologię. Przykładem może być utwór Loss of Grasp [Utrata kontroli] z 2010 roku francuskich autorów Serge'a Bouchardona i Vincenta Volckaerta ${ }^{26}$, w którym w pewnym momencie czytelnik musi wpisać na klawiaturze dowolny tekst, natomiast maszyna sama decyduje o tym, co wyświetli się na edytorze. Ten zabieg nazwany został przez badaczkę e-literatury Giovannę Di Rosario nową figurą retoryczna, interfejsową sprzecznością (interfacial antagonism), powstająca na styku sztuki słowa i technologii. Jeśli zatem chcielibyśmy uznać za użyteczną sprzecznościową regułę Balcerzana, to z tym zastrzeżeniem, że odnosi się ona do wszystkich form komunikacji, w których ujawnia się wskazana przez Balcerzana formuła. Opisywane przez niego antynomie, generujące energię literackości, realizują się dziś bowiem także $\mathrm{w}$ środowisku multimedialnym, choć w mocy pozostaje poczynione przez badacza zastrzeżenie, że „dzięki tej właśnie energii komunikacja sensu stricto literacka ostro odcina się od pozostałych rodzajów komunikacji werbalnej, stając się transmisją przekazów na wpół zrozumiałych”27. Dodać jednak należałoby, że owa energia literackości nie daje się zamknąć w myśleniu modelowym. Wyczucie literackości, na które powołuje się badacz ${ }^{28}$, pozwala dziś tropić jej przejawy w rejonach bardzo odległych od tradycyjnych lokalizacji literatury ${ }^{29}$.

Literackość dzieł nowomedialnych broni się poprzez swoją przynależność do kultury grafemicznej. Chce być czytana w kontekście historii i tradycji

${ }^{26}<$ https://anthology.elmcip.net/works/loss-of-grasp.html> [dostęp: 5.07.2018]. Utwór nagrodzony został New Media Writing Prize 2011.

${ }^{27}$ E. Balcerzan, Literackość..., s. 75.

${ }^{28}$ Tamże, s. 139.

${ }^{29}$ Jakkolwiek istnienie takich instytucji jak amerykańska Electronic Literature Organization (ELO) przy MIT, która gromadzi najciekawsze egzemplifikacji literatury elektronicznej z całego świata czy Anthology of European Electronic Literature (ELMCIP), jak również działalność w Polsce Hubu Wydawniczego Rozdzielczość Chleba i Korporacji Ha!Art, które udostępniaja polskie utwory cyfrowe, zdają się potwierdzać zdanie Balcerzana: „Właśnie dlatego, że z uniwersum tworów językowych potrafimy wyczuć fenomeny literackie, możemy w mowie potocznej dyskutować o takich zjawiskach społecznych - i uczestniczyć w nich - jak kultura literacka, życie literackie, komunikacja literacka, środowisko literackie (twórców), wreszcie publiczność literacka (odbiorców). Bez norm odróżniania i odgraniczania literatury od innych postaci mowy nie funkcjonowałyby instytucjonalne ramy - prawa autorskie, stowarzyszenia twórcze, katalogi bibliotek, kanony lektur" (E. Balcerzan, Literackość..., s. 139-140). Kwestia ta jednak wymagałaby dodatkowego komentarza. 
form literackich, na ich tle definiuje swoją odrębność. Na pytanie o literackość wielu cyfrowych zjawisk nie zawsze odpowiedź jest jednak oczywista. Tutaj to, co dzieje się pomiędzy - w dziełach hybrydycznych, bytach zmieszanych, nieprzynależących w całości do żadnej z tradycyjnych klasyfikacjiwydaje się lepiej odzwierciedlać stan rzeczywisty aniżeli próby poszukiwania odpowiedzi na pytanie o granice literatury dzisiaj. Literatura bowiem nie ma granic: można natrafić na nią wszędzie, miesza się ona z formami i mediami o odmiennym statusie, zaraża je wrażliwością na językowy aspekt komunikacji, na jego walory estetyczne i semantyczną głębię, ale sama także nie pozostaje obojętna na specyfikę kultury multimedialnej.

Dlatego dzisiejsze badania zjawisk przekraczających dotychczasowe podziały i systematyzacje skupić powinny się, z jednej strony, na procesie współoddziaływania infertejsów (czyli softwaru z warstwą językową komunikacji), z drugiej zaś na tym, jak te zjawiska konstruuja społeczno-kulturowy kontekst, jak oddziałują na użytkowników, których percepcyjne możliwości i kompetencje poddawane są nieustannym próbom i przekształceniom.

Literackość chciałabym zatem traktować jako estetyczne doświadczenie ważności tego, w jaki sposób funkcjonuje język w przekazie. Gdy znaczenie komunikatu językowego wysuwa się na plan pierwszy - nie mamy kłopotu z identyfikacją obiektów jako przynależnych do literatury (e-literatury), kiedy jednak kod werbalny jest tylko jednym z kodów pojawiajacych się w dziele, jego rozpoznanie staje się kłopotliwe. Często w takich przypadkach używa się terminu net-art, ponieważ jest pojemniejszy i wskazuje na multimedialność zjawisk cyfrowych. Co bowiem zrobić z takimi wytworami jak memy, animacje, wirtualne instalacje, w których pojawiają się słowa w różnych i niejednoznacznych funkcjach? Właśnie w takich sytuacjach użyteczniejsza może okazać się kategoria literackości, pozwala bowiem skupić się na aspektach literackich obiektu/projektu/instalacji/artystycznego wydarzenia, którego natura i właściwości wymykają się jednoznacznej klasyfikacji. Przy czym pamiętać trzeba, że nie sposób jednoznacznie wytyczyć granic literackości zjawisk w przekazach multimedialnych. Nie tylko dlatego, że nie ma ona natury esencjalnej, lecz również dlatego, że jej funkcjonalność jest kwestią interpretacji.

Bardzo trudno rozstrzygnąć o rzeczywistych właściwościach słowa w oderwaniu od konkretnej sytuacji komunikacyjnej. Podczas interaktywnego odbioru dzieł multimedialnych często to warstwa wizualna przykuwa całą uwagę odbiorcy, język zaś staje się przezroczysty, wehikularny. Kiedy jednak z tym samym dziełem obcuje osoba o wrażliwości (i wykształceniu) literackim, te same elementy moga zostać potraktowane w zupełnie inny sposób. Na plan pierwszy wysuna się wówczas estetyczne, literackie walory słowa, sama zaś literackość będzie promieniować na inne aspekty projektu. 
Taka optyka pozwala badać zjawiska nowomedialne z różnych punktów widzenia. Dla literaturoznawcy atrakcyjne są one właśnie jako świadectwo oddziaływania literatury na inne sztuki, jakkolwiek nadużyciem byłoby twierdzenie, że literatura jako sztuka w nowych mediach zajmuje pozycję uprzywilejowaną lub dominująca na przekazem wizualnym. Nic nie stoi jednak na przeszkodzie, by - nawet jeśli tylko metaforycznie - mówić o literackości (poetyckości) pewnych rozwiązań, ujęć czy kompozycji dzieł multimedialnych. Uwypukla je jednak zawsze obecność komunikatu językowego. Dlatego, próbując prowizorycznie i bardzo umownie wytyczyć granice zainteresowania zjawiskami multimedialnymi w Internecie i - znów tylko umownie - oddzielić je od net-artu, przyjąc można dwa podstawowe kryteria:

1) autorskie - gdy autor wprost wskazuje na literacki charakter swojego przekazu i wolę, by był on w kontekście innych utworów literackich interpretowany. Często artysta sam określa genologiczną i rodzajową przynależność swojego utworu (powieść: graficzna, kolaboratywna, hipertekstowa, SMS-owa, poezja wizualna, wideopoezja, cyberpoezja, poezja wizualna, e-poezja, poemat elektroniczny). Wówczas nawet spór o literackość obiektu toczy się w świetle gatunkowej charakterystyki dokonanej przez twórcę. Doskonały przykład tego rodzaju autorsko-instytucjonalnej klasyfikacji stanowi trzytomowa Kolekcja Literatury Elektronicznej (Electronic Literature Colection) opublikowana online przez MIT. Czytelnik znajdzie tam całe spektrum eksperymentów z softwarem i możliwościami multimediów, przy czym w centrum krytycznej refleksji i uwagi wszystkich 180 umieszczonych tam dzieł pozostaje siła i możliwości ekspresji literackiej (poetyckiej) w nowym digitalnym środowisku;

2) funkcjonalne - gdy w utworze zauważyć można wyraźną dominację słowa, co do statusu którego możemy przyjaćc, że zakłada kontekst komunikacji literackiej; wówczas odbiorca sam może przyjąć, że ma do czynienia $\mathrm{z}$ odmianą dzieła e-literackiego. Zawsze jednak w takim przypadku jest to kwestia typu wrażliwości, kompetencji, sposobu i celu odbioru - a zatem bardzo subiektywna.

Analogicznie do problemów dotyczących poezji wizualnej i konkretnej, w których wzajemna relacja aspektów wizualnych, typograficznych i plastycznych oraz semantyka przekazu językowego budzą wątpliwości co do ich czystości rodzajowej, można odsunąć wskazane wyżej zjawiska na margines zainteresowań badawczych, traktując je jako drugorzędne, a przynajmniej marginalne (peryferyjne) dla literaturoznawstwa. Istnieje bowiem i cały czas powstaje (a przekonana jestem, że to się nie zmieni) literatura drukowana, którą literaturoznawca komfortowo może badać. Ale przecież jednocześnie w obrębie rzeczywistości wirtualnej rozwija się coraz rozleglejszy zespół zjawisk e-literackich, domagajacych się opisu. Czy zatem zostawić je medio- 
znawcom? Z pespektywy badaczki wyposażonej w świadomość i narzędzia literaturoznawcze jest mi trudno zgodzić się na takie - pozorne tylko, bo będące w istocie unikiem i wyparciem - rozwiązanie. Mam bowiem głębokie przekonanie, że zjawiska te należą do obszaru literaturoznawstwa, którego pole, tak jak pole literatury, po prostu nieustannie poszerza się i przekształca, czyniąc przedmiot poznania literaturoznawców dużo bardziej niż dotąd złożonym, rozproszonym i zmąconym. I jest to wniosek w gruncie rzeczy i dla literatury, i dla literaturoznawców niezwykle optymistyczny. Nie o to wszak chodzi w namyśle nad współczesnymi zjawiskami sztuki, by kategoryzować je, szufladkować i rozdzielać, lecz by ukazywać skomplikowane sploty i wzajemne uwikłania, które wytyczanie granic uniemożliwiaja. Przedmiotem zainteresowania literaturoznawcy powinny być nie tylko dzieła i procesy, lecz również praktyki kulturowe związane z czytaniem, pisaniem i innymi typami zachowań towarzyszącymi obecności słowa w przestrzeni kultury, również technokultury.

Ktoś mógłby powiedzieć, że aby czytać książkę, nie trzeba znać technologii produkcji papieru, nie ma więc potrzeby, by zgłębiać tajniki programowania, by badać e-literaturę. I trudno się z takim wyjaśnieniem nie zgodzić. Taki argument wydaje się jednak przekonujący tylko do momentu, gdy spróbujemy zmierzyć się z praktyką artystyczną i opisać poetykę tych e-literackich obiektów. Okaże się bowiem dość szybko, że narzędzia literaturoznawcze nie dostarczają odpowiedzi na pytania kluczowe dla badacza. Mianowicie: jak to jest zrobione? W ujęciu semiotycznym, proponowanym przez polskich badaczy e-literatury ${ }^{30}$, oznacza to tyle, że znak w dziele e-literackim ma jeszcze dodatkowa, cyfrową warstwę. W definicji znaku digitalnego jest ona istotna dla sposobu konstruowania warstwy kulturowej, czyli tej, z którą mamy do czynienia, spoglądając na ekran urządzenia. A kiedy weźmiemy pod uwagę tak zwane dzieła kodowe - osobny, obficie reprezentowany gatunek twórczości elektronicznej, w którym elementy kodu informatycznego zostają wplecione w tekst i stają się częścią widocznego na ekranie utworu - jasne staje się, że tak jak twórca programujący/ piszący swój e-literacki utwór musi korzystać z pomocy programisty albo sam być programista, tak badacz e-literatury musi zwrócić się o pomoc do informatyka. Najlepiej zaś byłoby, gdyby sam opanował podstawy programowania. Kod informatyczny można bowiem również czytać, ma on swoje znaczenie i funkcje. Dostęp do kodu źródłowego utworu e-literackiego sporo może badaczowi e-literatury powiedzieć o właściwościach samego dzieła. To właśnie z tego powodu w Stanach Zjednoczonych, gdzie e-literatura roz-

${ }^{30}$ Przekaz digitalny. Z zagadnień semiotyki, semantyki i komunikacji cyfrowej, pod red. E. Szczęsnej, Kraków 2015. 
wija się intensywnie i w bardzo różnorodnych formach, wykorzystując coraz to nowe możliwości software'u, powstają podręczniki programowania dla humanistów, umożliwiające twórcom korzystanie z podstawowych narzędzi do kreowania/pisania obiektów literatury elektronicznej, a odbiorcom wgląd w specyfikę warsztatu autora takiej nowej literatury. Także na polskim rynku ukazał się pierwszy, przełożony z języka angielskiego, podręcznik podstaw programowania dla e-literatów i e-literaturoznawców, autorstwa Nicka Montforta - praktyka i teoretyka mediów cyfrowych ${ }^{31}$.

Najważniejszą konkluzją z powyższych rozważań jest, że - właśnie z powodu przemian, jakie nastapiły w nauce, kulturze i technologii - wielu kategorii i zjawisk funkcjonujących dotąd w świadomości odbiorców i badaczy jako odrębne, w dzisiejszym technokulturowym świecie wyodrębnić się już nie da. Splotły się one bowiem ze sobą nie na poziomie dyskursu, a nawet nie na poziomie ich percepcji i doświadczenia, lecz ontologii, czyli tego, jak istnieja, jaka jest ich geneza i status. Warto przytoczyć słowa badaczy zajmujących się przekształceniami obszaru zainteresowań humanistyki: „Nowe praktyki twórcze są nastawione na działania w obrębie [...] technokultury, a więc splotu tego, co niegdyśs definiowane było jako obszary osobne, dziś natomiast musi być ujmowane wspólnie, jako fenomen wyrażający zmiany, które zaszły w nowoczesności”’32.

To, co Agnieszka Jelewska i Michał Krawczak nazywają symbiotycznymi splotami, synergią i jednoczesną hybrydyzacja, a Piotr Zawojski syntopią sztuki, nauki i technologii ${ }^{33}$, charakteryzuje nie tylko wewnętrzna sytuację sztuki i innych dziedzin ludzkiej aktywności, lecz również określa nowy stan rzeczywistości, która oplataja wirtualne sieci komunikacji i przepływu informacji. Nie sposób myśleć dziś o relacjach społecznych i praktykach kulturowych, a także o procesach poznawczych, nie uwzględniając tego, że stanowią one efekt oddziaływania technologii, która zazwyczaj w sposób niewidzialny i nieuświadamiany przenika i przekształca każde doświadczenie. Tak właśnie dzieje się ze sztuka, w tym z literaturą elektroniczna, na której przykładzie dobrze można unaocznić zjawisko zacierania granic pomiędzy sztuka i technologia, pomiędzy działaniem naukowym i artystycznym, pomiędzy postawą twórcy i badacza, a także pomiędzy postawą odbiorcy i kreatora.

Aby rozstrzygnąć ewentualne wątpliwości dotyczące tego, czy owo zacieranie granic między sztuką i technologia, między dziedzinami sztuki oraz

${ }^{31}$ N. Montfort, Odkrywanie kodu. Wprowadzenie do programowania w sztuce $i$ humanistyce, przeł. M. Tabaczyński, M. Pisarski, A. Ladziński, Kraków 2017.

${ }^{32}$ A. Jelewska, M. Krawczak, Zakończenie; symbiotyczne sploty, [w:] Sztuka i technologia $w$ Polsce, pod red. A. Jelewskiej, Poznań 2014, s. 262.

${ }^{33}$ Por. P. Zawojski, Cyberkultura. Syntopia sztuki, nauki i technologii, Warszawa 2010. 
między dyscyplinami, określane często mianem transdyscyplinarności, jest kolejną intelektualną modą czy reakcją na fundamentalne przekształcenia naszej rzeczywistości, warto odwołać się do stanowiska jednego z czołowych teoretyków mediów, Roya Ascotta, który już ćwierć wieku temu zdiagnozował rewolucyjną zmianę paradygmatu kulturowego, wskazując jako jej istotę przejście od przedstawiania stałych wyglądów do płynnego i ulotnego ukazywania się. Formułując pytanie o wpływ technologii na ludzką świadomość i sposób postrzegania rzeczywistości, badacz pokazuje, że klasyczne wyobrażenia stabilnej i niezmiennej rzeczywistości oraz sztuki, która ją reprezentuje w postaci stałych, niezmiennych obiektów, utraciły całkowicie swoja aktualność w świecie przenikniętym przez teleinformatyczne technologie, w których zamiast widzialnej stałości powierzchni rzeczy liczą się płynne i dynamiczne procesy, niedające się zatrzymać ani jednoznacznie zdefiniować. To, zdaniem Acotta, oznacza śmierć tradycyjnej sztuki, która w galeriach, muzeach i na wystawach gromadziła obiekty powstałe jako efekt przeświadczenia o jednolitości perspektywy przedstawienia, semiotycznej stabilności tekstów kultury, ciagłości kulturowej i ich niezmienności. Właśnie z tego powodu to, co zaszło współcześnie za sprawą nauki i technologii, Ascott nazywa zmiana paradygmatyczna:

Tym, co sztuka i technologie cyberkultury są w stanie pokazać, jest fakt, że nastapiła radykalna zmiana w postrzeganiu naszych zwiąków z rzeczywistościa. Nacisk przesunął się z wyglądu na pojawianie się [from appearance to apparition], czyli od zewnętrznego i widocznego wyglądu rzeczy do wewnętrznych i emergentnych procesów stawania się. W tej kulturze ani dokładny stan sztuki, ani jej status kulturowy nie mogą zostać ustalone lub zdefiniowane; są w stałym stanie transformacji. To nie jest stan przejścia między dwiema znanymi i ustalonymi definicjami lub kierunkami, a raczej sama transformacja jako definiująca charakterystyka, nierozerwalnie związana ze specyfiką sztuki interaktywnej, dla której skomponowany i skończony obiekt był klasycznym poprzednikiem. Sztuka interaktywna to sztuka w stanie nieskończonego stawania się. To jest sztuka-wdziałaniu, strumień. Tak jest obecnie zarówno w niezależnych systemach, czy to $\mathrm{w}$ formacie hipermedialnym lub multimedialnym, czy w Internecie $\mathrm{z}$ jego globalna różnorodnością wejść i wyjśćc ${ }^{34}$.

Choć powyższe uwagi nie odnoszą się wprost do przemian literatury digitalnej, lecz do sztuki cyfrowej w ogóle, warto odnotować, że także w obrębie projektów e-literackich cyfrowa technologia dała artystom nowe możliwości wykorzystania procesualności. Dynamizm liter i tekstów oraz kształtów, a także niemożność ich pochwycenia w całości, nieistniejącej po prostu

${ }^{34}$ R. Ascott, From appearance to apparition: Communication and culture in the cybersphere, „Leonardo Electronic Almanac”, I. 2. October 1993, przeł. - E.W. <http://leoalmanac. org/journal/Vol_1/lea_v1_n02.txt> [dostęp: 11.07.2018]. 
jako stabilny i statyczny stan, dają poczucie zaglądania pod powierzchnię widzialnego, odkrywania niestabilności i zmienności nie tylko znaczeń, ale także znaków, przedmiotów i stanów rzeczy. Nowe narzędzia pozwalają twórcom na konstruowanie takich projektów, które stanowią już nie reprezentację widzialnego, lecz urzeczywistniaja (w akcie performatywnej lektury) doświadczenie procesualności, płynności i niepochwytności, właściwe dzisiejszemu usieciowionemu światu. Rzeczywistość konstruowana online staje się niestabilna przestrzenią subiektywnych wrażeń, marzeń i pragnień twórcy, który nie tyle próbuje coś wyrazić, lecz projektuje scenariusze sytuacji, w których to odbiorca będzie kreatorem istotnych indywidualnie dla niego, ale też społecznie, znaczeń ${ }^{35}$.

Sztuce digitalnej i znacznej części e-literatury udaje się uchwycić wspólne wszystkim użytkownikom cyfrowych technologii poczucie braku stabilności oraz istnienia granic naszego świata, które umożliwiałyby nadanie mu stałych form reprezentacji. Odpowiedzią na ten typ doświadczenia były już ćwierć wieku temu postulaty Roya Ascotta:

Chcemy teraz sztuki, która konstruuje nowe rzeczywistości, nie takiej, które reprezentuje świat z góry określony, skończony i gotowy. Chcemy teraz sztuki raczej instrumentalnej niż ilustracyjnej, wyjaśniającej lub ekspresywnej. Zamiast po prostu upiększyć świat i dodawać mu ornamenty, artysta cyberkulturowy pragnie zaangażować się w jego odnowienie i przebudowę $e^{36}$.

Wykorzystując możliwości, jakie daje oprogramowanie graficzne, twórcy utworów e-literackich mogli podjąć eksperymenty z nowymi sposobami zagospodarowywania czasoprzestrzeni dzieła, która w medium cyfrowym nie należy już tylko do świata przedstawionego, lecz stała się realnym doświadczeniem trwania, zmienności i trójwymiarowości komunikacji literackiej. To pozwoliło literatom-programistom na skupienie się nie tylko na warstwie konstrukcyjnej utworu (jego poetyce), lecz także na planowaniu możliwych sytuacji odbiorczych. Ten wymiar projektowania kontekstu dzieła staje się istotnym novum w świecie literatury cyfrowej. Odbiorca może poczuć się teraz współtwórca, odpowiedzialnym za wytwarzanie konkretnej wersji zdarzenia, jakim staje się e-literacki obiekt w trakcie interaktywnej lektury. Doskonale prezentuja te sytuacje zapisy happeningów mających

${ }^{35}$ Gwoli ścisłości Acott wyjaśnia jednak, że to nie za sprawą technologii cyfrowej do sztuki wszedł problem widzialności oraz doświadczenia ruchu. Konceptualnie sztuka telematyczna, jako akcja, jako proces, sztuka w działaniu, transformacja, zmiana, strumień i ruch, nie wywodzi się z technologii, lecz ma swoje źródła w dziele Pollocka. Warto wskazać dużo odleglejsze źródła - starożytne, zarówno w sztuce, jak i filozofii (Heraklit, malowidła naskalne naśladujące ruch).

${ }^{36}$ R. Ascott, dz. cyt. 
miejsce w trakcie publicznych prezentacji e-literackich projektów, dostępne na stronie $\mathrm{ELO}^{37}$.

O skali i wadze zmian, które zachodzą w literaturoznawstwie, świadczyć może także to, że w świadomości najbardziej konsekwentnych obrońców autonomii literatury pojawiają się głosy poświadczające świadomość zmiany jej sytuacji. Interesujący przykład tego zjawiska stanowi przywoływana już tutaj obszerna rozprawa Edwarda Balcerzana Literackość. Autor prezentuje w niej spójny, finezyjny i bardzo drobiazgowy wykład strukturalistyczno-semiotycznej teorii literatury oraz literackości. Świadom, że kulturowe fakty podlegaja nieustannej autointerpretacji i nigdy nie podporządkowują się teorii, jednocześnie uznaje za swój jako naukowca obowiązek podejmowanie prób wprowadzenia choćby względnego ładu do refleksji nad problemami zajmującymi klasycznego literaturoznawcę. Buduje zatem sytuacje modelowe, czyli rodzaj idealizacyjnego modelu poznawczego, majacego walor mapy ułatwiającej orientację wśród ogromu złożonych zjawisk będących przedmiotem zainteresowania literaturoznawcy. Równocześnie zaś, konsekwentnie broniąc autonomii dyscypliny oraz systemowości literatury, w swojej propozycji nowej genologii, sformułowanej dwadzieścia lat temu, organizuje porządki i podziały, które uwzględniają zmiany zachodzące w kulturze. Wprowadza pojęcie genologii multimedialnej, którą definiuje jako „dział semiotyki - analizujący i systematyzujący genologiczne konsekwencje istnienia wielu różnych przekaźników w przestrzeni kultury”38. Odnotowuje też, że ,izolacja literatury jako faktu monomedialnego, spowodowana wynalazkiem Gutenberga, staje się poważnie zagrożona w epoce upowszechnienia Internetu” 39 i przewiduje, że „prawdopodobnie przekazy polimedialne staną się powszechną normą komunikacyjna" 40 .

Przywołuję stanowisko autora $W$ strone genologii multimedialnej, ponieważ świadczy ono o tym, że również w obrębie zachowawczego literaturoznawstwa nie budzi wątpliwości potrzeba poszerzenia perspektywy oglądu zjawisk, które przekraczają (choć w ujęciu Balcerzana nie znosza) granicę

${ }^{37} \mathrm{http} / / /$ collection.eliterature.org/

${ }^{38}$ E. Balcerzan, W stronę genologii multimedialnej, „Teksty Drugie” 1999, nr 6, s. 10-11. Ten sam artykuł został następnie w minimalnie zmienionej wersji przedrukowany w: E. Balcerzan, Literackość..., s. 407-430. W niniejszym artykule odwołuję się do pierwodruku.

${ }^{39}$ Tamże, s. 19.

${ }^{40}$ Tamże, s. 19. Niestety, Balcerzan nie uwzględnia innej niż literaturoznawcza optyki i medium traktuje jako przekaźnik mający co prawda wpływ na komunikację literacka, ale raczej jako techniczne urządzenie, a nie technologię, która przekształciła kulturowy paradygmat. Dlatego badacz nie bierze pod uwagę rangi, skali i skutków zmian, które zaszły w kulturze od czasu, gdy napisał swój artykuł. Świadczy o tym fakt, że umieścił go, po upływie nieomal dwóch dekad, w książce poświęconej literackości w właściwie niezmienionej formie, nie aktualizując także stanu badań na temat omawianych problemów. 
sztuki i niesztuki ${ }^{41}$. Analizując złożoność zjawisk obecnych we współczesnej semiosferze, obejmującej zarówno jej procesy oraz stany werbalne, jak i niewerbalne, autor Literackości dochodzi do wniosku, że projektowana przez niego Nowa Genologia musi odejść od klasycznych porządków i objąć swoim zasięgiem nie tylko ,artystyczne, paraartystyczne i nieartystyczne formy komunikacji piśmienniczej" ${ }^{2}$. Poddając rewizji swoje wcześniejsze stanowisko, stwierdza: „Dziś sądzę, że wyróżnione przeze mnie paradygmaty przekraczają monomedialne granice piśmiennictwa (czy mowy) mogą być traktowane jako rozwijające się równolegle w innych kodach i mediach" ${ }^{43}$.

Trzeba przyznać, że jest to stwierdzenie przełomowe, które wszystkim nieprzekonanym do sensowności poszerzenia pola badań nad literackością daje zielone światło do podjęcia takiej próby. Badacz nie uwzględnia, co prawda, w swojej klasyfikacji konwergencji mediów i jej konsekwencji. Niemniej - perspektywa, którą proponuje, jest świadectwem wagi i siły oddziaływania przemian, które nie pozostawiły obojętnym nikogo, kto z uwaga i wnikliwością przygląda się kulturowym procesem współczesności.

Na koniec tych rozważań, w których problem przekraczania, zacierania, rozpraszania, osłabiania i znoszenia granic między sztuką a technologia, literaturą elektroniczną a innymi sztukami cyfrowymi, a także między klasycznym literaturoznawstwem a współczesną humanistyką otwierająca się na wszystkie aspekty wiedzy o świecie (także te związane z kategorią nie-ludzkiego), stanowił motyw przewodni i główny przedmiot namysłu, chciałabym przywołać uwagę Ryszarda Kluszczyńskiego - badacza, który problematykę technokulturowych przekształceń współczesnej sztuki rozpoznał jak mało kto:

Współczesna sztuka nie mieści się już [...] w ramach poszczególnych dyscyplin, nie pozwala ująć się analitycznie, a tym bardziej uporządkować za pomocą tradycyjnych kategorii poznawczych. Epoka społeczeństw sieciowych, multiplikujących się światów i zmiennych, nieprzerwanie rekonstruowanych tożsamości, epoka, w której komunikowanie staje się podstawowa formą aktywności społecznej oraz fundamentem i zasadą funkcjonowania instytucji organizujacych te praktyki, nie sprzyja artystycznej czystości rodzajowej ani poszukiwaniom cech specyficznych. Twórczość dnia dzisiejszego, ta przynajmniej, która prowadzi dialog ze współczesnościa, to polifoniczna, wielotworzywowa, wielowymiarowa sztuka medialna, intermedialna, hipermedialna, do skrajności doprowadzająca zainicjowany niegdyś przez romantyzm proces korespondencji sztuk ${ }^{44}$.

\footnotetext{
${ }^{41}$ Por. E. Balcerzan, $W$ strone genologii..., s. 20.

${ }^{42}$ Tamże, s. 19 - wyróżn. E.B.

${ }^{43}$ Tamże, s. 19-20.

${ }^{44}$ R.W. Kluszczyński, Stowo wstępne, [w:] (Nie)obecne granice, pod red. K. Kuropatwy, D. Rode, Kraków 2003, s. 9.
} 
Otóż wydaje się, że w najnowszych ujęciach nikt już nie dąży do określenia tożsamości literatury. Na tym właśnie polega owa niezwykle ważna, paradygmatyczna zmiana kulturowa, którą refleksja jedynie potwierdza, a nie konstruuje (kulturowa realność poprzedza bowiem jej opis), że-i dzieje się to za sprawa technologii cyfrowych - rozmywa się i zaciera tożsamość sztuk. Dlatego w odniesieniu do nowych, digitalnych zjawisk bardziej niż kategoria literatury sprawdza się kategoria literackości, której obecność w różnych obszarach sztuki jest niekwestionowana. Literaturoznawca, który pogodzi się z tą zmiana, ma jeszcze więcej pracy niż dawniej, musi bowiem rozpoznać i opisać metamorfozy i przygody literackości w nowej technokulturowej rzeczywistości.

\section{BIBLIOGRAFIA}

Aarseth E.J., Cybertekst. Spojrzenia na literaturę ergodyczna, przedm. M. Tabaczyński, przeł. D. Sikora, M. Pisarski, P. Schreiber, M. Tabaczyński, Kraków 2014.

Arendt H., Kondycja ludzka, przeł. A. Łagodzka, Warszawa 2000.

Ascott R., From appearance to apparition: communication and culture in the cybersphere, „Leonardo Electronic Almanac” I. 2. October 1993, <http://leoalmanac.org/journal/ Vol_1/lea_v1_n02.txt> [dostęp: 11.07.2018].

Balcerzan E., Literackość. Modele, gradacje, eksperymenty, Toruń 2013.

Balcerzan E., W strone genologii multimedialnej, „Teksty Drugie” 1999, nr 6, s. 7-24.

Bodzioch-Bryła B., Ku ciału post-ludzkiemu. Poezja polska po 1989 roku, Kraków 2006. Bouchardon S., Volckaert V., Loss of grasp, <https://anthology.elmcip.net/works/loss-ofgrasp.html> [dostęp: 20.07.2018].

Celiński P., Postmedia: cyfrowy kod i bazy danych, Lublin 2013.

Doda-Wyszyńska A., Pojęcie techne a filozofia przedstawienia, [w:] Filozofia technologii, red. S. Myoo, J. Hańderek, Lublin 2014, s. 7-16.

Electronic Literature Collection, <http://collection.eliterature.org/> [dostęp: 21.07.2018].

Gajewska G., Arcy-nie-ludzkie. Przez science fiction do antropologii cyborgów, Poznań 2010.

Gitelman L., Always Already New. Media, History, and the Data of Culture, Cambridge 2006.

Hopfinger M., Literatura i media: po 1989 roku, Warszawa 2010.

Jelewska J., Krawczak K., Zakonczenie; symbiotyczne sploty, [w:] Sztuka i technologia $w$ Polsce, red. A. Jelewska, Poznań 2014, s. 261-264.

Kay A., Personal dynamic media, [w:] The New Media Reader, eds N. Wardrip Fruin, N. Montfort, Cambridge 2003, s. 393-404.

Klan cyborgów. Mariaż człowieka z technologia, red. G. Gajewska, J. Jagielski, Gniezno 2008.

Kluszczyński R.W., Stowo wstepne, [w:] (Nie)obecne granice red. K. Kuropatwa, D. Rode, Kraków 2003.

Liternet. Literatura i Internet, red. P. Marecki, Kraków 2002. 
Manovich L., Awangarda jako software, przeł. I. Kurz, „Kwartalnik Filmowy” 2001, nr 35-36, s. 323-335.

Manovich L., Estetyka postmedialna, przeł E. Wojtowicz, [w:] Redefinicja pojęcia sztuka: ponowoczesność i wielokulturowość, red. J. Dąbkowska-Zydroń, Poznań 2006.

Manovich L., Język nowych mediów, przeł. P. Cypryański, Warszawa 2006.

Montfort N., Odkrywanie kodu. Wrowadzenie do programowania w sztuce i humanistyce, przeł. M. Tabaczyński, M. Pisarski, A. Ladziński, Kraków 2017.

Przekaz digitalny. $Z$ zagadnień semiotyki, semantyki $i$ komunikacji cyfrowej, red. E. Szczęsna, Kraków 2015.

Strachey Ch., Love letter algorithm, <https://www.gingerbeardman.com/loveletter/> [dostęp: 20.07.2018].

Sztuka i technologia. Od cyberkomunizmu do kultury makerów, red. A. Jelewska, Poznań 2014.

Zawojski P., Cyberkultura. Syntopia sztuki, nauki i technologii, Warszawa 2010. 
